\title{
Leptin Genotype Is Associated with Lactation Performance and Health of Holstein Cows
}

\author{
R. C. Chebel, ${ }^{*}$ F. Susca, ${ }^{*}$ and J. E. P. Santos ${ }^{1}$ \\ ${ }^{*}$ Cooperative Extension, School of Veterinary Medicine, University of California-Davis, Tulare 93274 \\ †Department of Animal Sciences, University of Florida, Gainesville 32611
}

\begin{abstract}
The objectives were to evaluate the associations among single nucleotide polymorphisms (SNP) in the $\mathrm{R} 4 \mathrm{C}$ locus in exon 2 of the leptin gene and the lactational performance and health of Holstein cows. Eight hundred and fourteen lactating dairy cows had their DNA sequenced in exon 2 of the leptin gene to determine the presence of SNP in the R4C locus. Cows were milked 3 times daily, and yields of milk and milk components were recorded monthly individually during the first 305 $d$ of lactation. Cows were examined daily by herd personnel for diagnosis of health events such as retained fetal membranes, displacement of abomasum, lameness, and mastitis. Resulting genotypes were CC (34.6\%), CT (48.2\%), and TT (17.2\%). Cows bearing the CT genotype had lower body condition $(2.98 \pm 0.02)$ during the first $62 \mathrm{~d}$ in milk (DIM) than cows homozygous for the $\mathrm{C}(3.02 \pm 0.02)$ and $\mathrm{T}(3.04 \pm 0.03)$ alleles. Leptin genotype was associated with yields of milk and milk components, and cows homozygous for the $\mathrm{C}$ allele were less productive than those carrying the CT and TT genotypes. The 305-d yields of 3.5\% fat-corrected milk, milk fat, and milk true protein were less in CC compared with CT cows by 258,12 , and $10.7 \mathrm{~kg}$, respectively. Cows carrying the TT genotype had increased incidence of displacement of abomasum (4.3\%), but genotype did not affect the incidence of retained fetal membranes, clinical and subclinical mastitis, or lameness. Risk of developing at least one clinical health disorder was influenced by leptin genotype, and cows carrying the CT genotype had the lowest risk for developing any disease (19.6\%). Mating decisions to increase the frequency of cows heterozygous in the $\mathrm{R} 4 \mathrm{C}$ locus may improve productivity and health.
\end{abstract}

Key words: dairy cow, health, leptin, single nucleotide polymorphism

Received November 23, 2007.

Accepted March 21, 2008.

${ }^{1}$ Corresponding author: jepsantos@ufl.edu

\section{INTRODUCTION}

Leptin is a peptide hormone secreted primarily by white adipocytes (Zhang et al., 1994) and it acts on the central nervous system as a satiety signal (Block et al., 2003) through specific receptors that are mainly expressed in the hypothalamus. During most of the lactation, the energy intake of dairy cows generally exceeds energy needs; however, in the first 4 to $8 \mathrm{wk}$ of lactation the reverse is observed, because voluntary DMI is insufficient to meet the nutrient needs of the lactating dairy cow. Therefore, early in lactation, milk yield is supported by strenuous mobilization of adipose tissue, resulting in loss of BW and BCS and a sharp decrease in concentrations of leptin, which reach the nadir approximately $10 \mathrm{~d}$ after parturition (Kadokawa et al., 2000). Reduced concentrations of plasma leptin signal the brain to conserve energy by lessening functions such as reproduction and immunity, which are not essential for short-term survival (Houseknecht et al., 1998). Thus, leptin is an important physiological marker of BW, DMI, energy expenditure (Houseknecht et al., 1998; Nkrumah et al., 2005), reproductive function (Cunningham et al., 1999), and certain immune functions (Lord et al., 1998).

Studies evaluating the presence of single nucleotide polymorphisms (SNP) in the promoter exon and intron regions of the bovine leptin gene and performance of cattle have demonstrated correlations between SNP and serum leptin concentration (Liefers et al., 2003; Nkrumah et al., 2005), feed intake (Liefers et al., 2002; Nkrumah et al., 2005), milk yield (Liefers et al., 2002; Buchanan et al., 2003; Kaminski et al., 2006), and body fat percentage (Buchanan et al., 2002; Nkrumah et al., 2004). The frequency of polymorphism in exonic sequences of the leptin gene was 1 per $84 \mathrm{bp}$.

The SNP in the R4C locus results in the substitution of a cytosine $(\mathrm{C})$ by a thymine $(\mathrm{T})$ nucleobase and the addition of an unpaired cysteine to the leptin protein, which has been suggested to influence its tertiary conformation and the affinity of leptin to its receptors (Konfortov et al., 1999; Liefers et al., 2003, 2005). Kinetic studies demonstrated that free leptin has a sig- 
nificantly shorter half-life than bound leptin, which could explain why cows homozygous for the $\mathrm{C}$ allele have greater concentrations of leptin than those homozygous for the $\mathrm{T}$ allele (Liefers et al., 2003). Therefore, interest exists regarding the potential relationships between SNP in the R4C locus of exon 2 of the leptin gene and productivity traits in dairy cattle. It is important to determine whether difference in genotype in cattle populations might in fact influence productivity and health, because of potential application of this technology for selection or arranged mating of cattle.

The hypothesis was that cows of different genotypes at the R4C locus of exon 2 of the leptin gene would have different lactational performance and would experience different incidence of health disorders during their lactation. Therefore, the objectives of the present study were to characterize the lactational performance and the incidence of health disorders in cows with R4C SNP in exon 2 of the leptin gene.

\section{MATERIALS AND METHODS}

\section{Animals, Housing, Diets, and Management}

Lactating Holstein cows, 458 multiparous and 356 primiparous, from a commercial dairy farm located in the San Joaquin Valley of California were used. The rolling herd milk production average was $12,035 \mathrm{~kg}$ of $3.5 \%$ FCM. Cows were housed in free-stall barns, and individual pens were similar in design, size, and number of cows housed. Primiparous and multiparous cows were housed separately. Cows calved from October 2003 to February 2004, and data were collected for the first $305 \mathrm{~d}$ of lactation.

Cows were fed 2 different diets as TMR according to the stage of lactation, with an immediate postpartum diet fed in the first 3 wk postpartum, and a lactating diet fed during the remainder of the lactation. Cows were fed twice daily and diets were based on corn silage, alfalfa hay, soybean meal, steam-rolled corn, whole cottonseed, calcium salts of palm oil, and a mineral and vitamin and protein supplement. The 2 diets were designed to meet or exceed the requirements set forth by the NRC (2001) for lactating Holstein cows weighing $650 \mathrm{~kg}$ and producing $45 \mathrm{~kg} / \mathrm{d}$ of milk containing $3.5 \%$ fat. All cows received $500 \mathrm{mg}$ of exogenous bST (Posilac, Monsanto Co., St. Louis, MO) every 14 d, initiated between 100 and $110 \mathrm{~d}$ postpartum until 2 wk before dry off.

Weekly, approximately $0.5 \mathrm{~kg}$ of TMR was sampled and dried at $55^{\circ} \mathrm{C}$ for $48 \mathrm{~h}$ in an air circulating oven. Dried samples were ground in a Wiley mill (Arthur H. Thomas Co., Philadelphia, PA) to pass a 2-mm screen, and then passed through a cyclone mill (Udy Co., Fort Collins, CO) to pass a 1-mm screen. Samples were com-
Table 1. Chemical composition of diets offered immediately after calving, in the first $3 \mathrm{wk}$ postpartum, and after $3 \mathrm{wk}$ postpartum

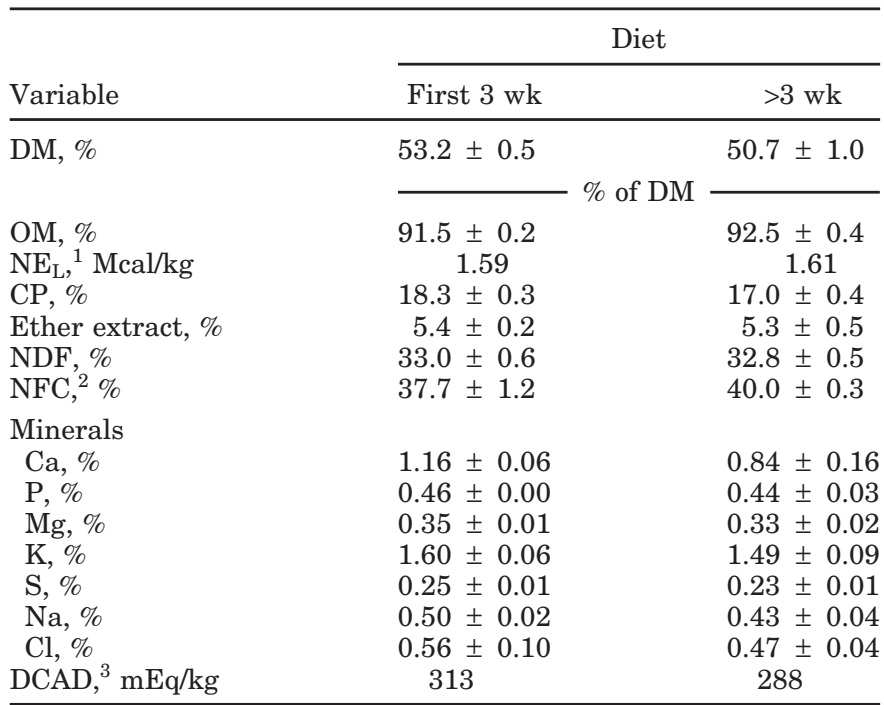

${ }^{1}$ Calculated from NRC (2001) based on nutrient composition of ingredients and the average DMI of 20 and $25 \mathrm{~kg} / \mathrm{d}$ for the first $3 \mathrm{wk}$ and after $3 \mathrm{wk}$ postpartum, respectively.

${ }^{2} \mathrm{NFC}=\mathrm{OM}-[\mathrm{CP}+(\mathrm{NDF}-\mathrm{CP}$ in $\mathrm{NDF})+$ ether extract $]$.

${ }^{3} \mathrm{DCAD}$ calculated according to the following formula: ( $\mathrm{mEq} \mathrm{Na}+$ $\mathrm{mEq} \mathrm{K})-(\mathrm{mEq} \mathrm{S}+\mathrm{mEq} \mathrm{Cl})$.

posited for 2-mo periods and analyzed for their contents of $\mathrm{DM}$ at $105^{\circ} \mathrm{C}, \mathrm{OM}$ and ether extract (AOAC, 2000), $\mathrm{ADF}$ and NDF (Van Soest et al., 1991), and minerals. The $\mathrm{N}$ content of samples was analyzed using an $\mathrm{N}$ analyzer (FP-528 Nitrogen Determinator, Leco Corporation, St. Joseph, MI), and CP was calculated by multiplying the $\mathrm{N}$ content by 6.25. Mineral content was analyzed at the Dairyland Laboratory (Arcadia, WI) using an inductively coupled plasma mass spectrometer (Thermo Jarrell Ash, Franklin, MA). Nutrient composition of diets fed is in Table 1.

\section{BCS and Yields of Milk and Milk Components}

Cows were scored for body condition ( $1=$ emaciated, $5=$ obese) at $3 \pm 3,35 \pm 3$, and $62 \pm 3$ DIM as described by Ferguson et al. (1994). Cows were milked 3 times daily and milk yields were recorded for individual cows once monthly during the official California DHIA test. Individual milk samples were collected from 3 consecutive milkings, composited, and analyzed for SCC, fat, and true protein concentrations (Foss 303 MilkoScan, Foss Foods Inc., Eden Prairie, MN) at the DHIA laboratory in Tulare, California. Data from 305-d yields of milk, fat, and true protein were obtained when cows completed 305 DIM or when they left the herd if earlier than 305 DIM from DHI records. 


\section{Incidence of Health Disorders}

Herd personnel evaluated cows daily for retained fetal membranes, displacement of abomasum, lameness, mastitis, and other miscellaneous diseases. Fetal membranes were considered retained if present past $24 \mathrm{~h}$ after calving. Diagnosis of left displacement of abomasum was based on the presence of an acute ping sound at auscultation and percussion on the left or right side of the abdomen. Cows diagnosed with left displacement of abomasum were treated by toggle pin suture procedure and those with displacement to the right side by surgery, supportive therapy with glucose precursors, and antibiotics were administered as needed. Clinical mastitis cases were characterized by the presence of abnormal milk or by signs of inflammation in one or more glands, and were treated by intramammary infusion of antibiotics according to treatment protocols established by the herd veterinarian. A cow had a new case of mastitis when a different gland was affected or when a period of $21 \mathrm{~d}$ had elapsed since the previous diagnosis. Incidence of lameness was determined based on diagnosis performed by visual observation of abnormal gait by herd personnel. In addition to evaluating individual diseases, the proportion of cows affected by at least one of the health problems described above was evaluated.

\section{Calving Data}

Calving difficulty was scored based on a 5-point scale; $1=$ no assistance, $2=$ slight assistance, $3=$ needed assistance; 4 = considerable force for extraction, and 5 = extreme difficulty (National Association of Animal Breeders, Columbia, MO). Cows with calving score $>2$ had dystocia. Sex of calf was recorded as female, male, or twins. Stillbirths were calves born at term but that died during or immediately after delivery before receiving colostrum and being moved to individual hutches.

\section{Blood Sample Collection and Leptin Genotyping}

Blood ( $7 \mathrm{~mL}$ ) was sampled from the median coccygeal vein or artery using evacuated tubes (Becton Dickinson, Franklin Lakes, NJ) containing $\mathrm{K}_{2}$ EDTA. Immediately upon collection, samples were placed in ice and transported to the laboratory. Whole blood samples were sent to Igenity (Lincoln, NE) for genotyping of the R4C locus of exon 2 of the leptin gene. Gentra kits (Qiagen Inc., Valencia, CA) were used for extracting DNA from the whole blood. Matrix-assisted laser desorption/ionization time-of-flight (MALDI-TOF) mass spectrometry (Sequenom, San Diego, CA) was used to capture the SNP allele.

\section{Study Design and Statistical Analyses}

Monthly yields of milk, 3.5\% FCM, fat and true protein, and concentrations of fat and true protein in milk, SCS, and BCS were analyzed by ANOVA as repeated measures using the MIXED procedure of SAS (SAS/ STAT, ver. 9.1; SAS Institute Inc., Cary, NC). The models included leptin genotype (CC, CT, and TT), parity (primiparous and multiparous), month postpartum, disease event (yes or no), interaction between genotype and month postpartum, and interaction between genotype and parity. Cow nested within genotype was used as the random error. The Schwarz Bayesian information criterion was utilized to identify the best covariance structure in the REPEATED statement for each dependent variable analyzed. The 305-d yields of milk, $3.5 \% \mathrm{FCM}$, fat, and true protein were analyzed by ANOVA with the GLM procedure of SAS (SAS Institute) with models that included the effects of leptin genotype, parity, disease, and interaction between genotype and parity.

Incidence of diseases was analyzed by logistic regression using the LOGISTIC procedure of SAS (SAS Institute). All models included leptin genotype, parity, and the interaction between genotype and parity, except for incidence of lameness, which did not include the interaction between genotype and parity because of a quasi-complete separation of data points. Body condition score at 3, 35, and 62 DIM and change in BCS from 3 to 35 and from 3 to 62 were only included in the logistic regression models when their effect on the outcome analyzed was $P \leq 0.20$ according to univariate analyses. Adjusted odds ratio and $95 \%$ confidence intervals were generated to compare the risk of disease among genotypes.

Treatment differences with $P \leq 0.05$ were considered significant and those with $0.05<P \leq 0.10$ were considered a tendency. For ANOVA, when overall treatment effect resulted in $P \leq 0.05$, mean separation and individual comparisons were then performed using the PDIFF statement in SAS (SAS Institute).

\section{RESULTS}

Eight hundred and fourteen Holstein cows had their $\mathrm{R} 4 \mathrm{C}$ polymorphism of the exon-2 region of the leptin gene sequenced to evaluate the occurrence of the arginine to cysteine mutation ( $\mathrm{C}$ to $\mathrm{T}$ ). The observed genotype frequencies were $34.6,48.2$, and $17.2 \%$ for CC, CT and TT, respectively, resulting in $82.8 \%$ of cows bearing the $\mathrm{C}$ allele and $65.4 \%$ bearing the $\mathrm{T}$ allele.

\section{BCS}

There was a tendency $(P=0.09)$ for the leptin genotype to influence BCS during the first 62 DIM (Figure 


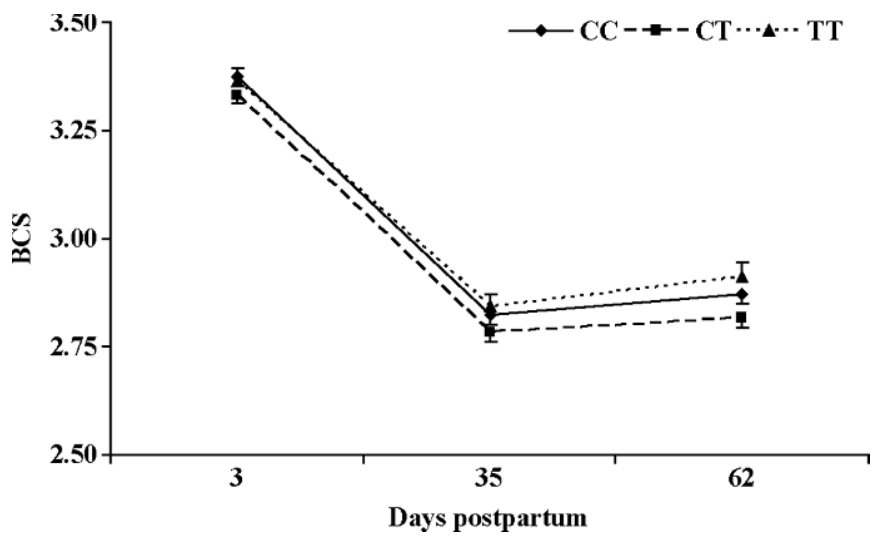

Figure 1. Body condition score of lactating Holstein cows according to their leptin genotype (a $\mathrm{C} / \mathrm{T}$ substitution resulting in an amino acid change from arginine to cysteine). The mean BCS during the first $62 \mathrm{~d}$ postpartum were $\mathrm{CC}=3.02 \pm 0.02, \mathrm{CT}=2.98 \pm 0.02$, TT $=$ $3.04 \pm 0.03$. Effect of leptin genotype $(P=0.09)$, day postpartum $(P$ $<0.01$ ), and interaction between genotype and month postpartum $(P=0.54)$.

$1)$, and CT cows had lower $(P=0.05)$ BCS than TT cows. Cows of different genotype experienced similar $(P=0.42)$ BCS loss from 3 to 35 DIM $(\mathrm{CC}=-0.58 \pm$ $0.03, \mathrm{CT}=-0.56 \pm 0.02, \mathrm{TT}=-0.53 \pm 0.03)$. The amount of BCS lost in the first 35 DIM by cows that experienced or did not experience diseases was not different $(P=$ 0.27 ), and they averaged $-0.57 \pm 0.03$ and $-0.54 \pm 0.02$ for cows with or without diagnosis of diseases, respectively. Similar to the first 35 d postpartum, BCS losses in the first 62 DIM did not differ $(P=0.13)$ among cows of different genotypes.

\section{Production Measures}

Cows with the CT genotype tended $(P=0.06)$ to have greater milk yield during the lactation before enrollment (Table 2). However, leptin genotype was not associated with monthly milk yield during the current lactation (Table 2). Cows that experienced at least one disease event during their lactation had lower $(P<0.01)$ milk yield than those that did not experience any disease events $(38.69 \pm 0.59$ and $40.91 \pm 0.46 \mathrm{~kg} / \mathrm{d}$, respectively). Monthly production of $3.5 \%$ FCM was influenced $(P=0.02)$ by leptin genotype, and cows homozygous for the $\mathrm{C}$ allele yielded less $3.5 \% \mathrm{FCM}$ than $\mathrm{CT}$ $(P=0.01)$ and TT $(P=0.04)$ cows $(\mathrm{CC}=39.2 \pm 0.6$ vs. $\mathrm{CT}=40.8 \pm 0.6$ vs. $40.9 \pm 0.7 \mathrm{~kg} / \mathrm{d})$, but CT and TT cows did not differ $(P=0.93)$. Cows that experienced at least one disease event during their lactation produced less $(P<0.01) 3.5 \% \mathrm{FCM}$ than those that did not experience disease events $(39.0 \pm 0.7$ and $41.6 \pm 0.5 \mathrm{~kg} / \mathrm{d}$, respectively).
Concentration of fat in milk was not affected by leptin genotype. Similarly, parity $(P=0.15)$ or occurrence of disease $(P=0.47)$ were not associated with fat concentration in milk (Table 2). Fat yield was influenced $(P=$ $0.02)$ by leptin genotype $(\mathrm{CC}=1.37 \pm 0.02 \mathrm{vs}$. $\mathrm{CT}=1.43$ \pm 0.02 vs. $1.43 \pm 0.02 \mathrm{~kg} / \mathrm{d}$ ), and cows homozygous for the $\mathrm{C}$ allele had lower production than $\mathrm{CT}$ and TT cows (Table 2). There was no $(P=0.90)$ difference in fat yield between CT and TT cows. Yield of fat was influenced $(P<0.01)$ by occurrence of diseases, in which cows diagnosed with at least one clinical disease event produced less milk fat than healthy cows $(1.37 \pm 0.02$ vs. $1.46 \pm$ $0.02 \mathrm{~kg} / \mathrm{d})$. Similar to concentration of fat, true protein in milk was not affected $(P=0.28)$ by leptin genotype, but it varied $(P=0.04)$ for primiparous and multiparous cows according to leptin genotype. For CC and TT cows, multiparous cows had greater concentrations of milk protein, whereas for CT cows, primiparous cows had milk with increased concentrations of true protein. Occurrence of disease affected $(P=0.05)$ true protein concentration, and cows that experienced disease had greater concentrations than cows that did not experience disease $(3.00 \pm 0.02$ vs. $2.97 \pm 0.01 \%)$. Leptin genotype affected $(P=0.04)$ milk true protein yield, and cows of CC genotype produced less true protein than $\mathrm{CT}$ cows $(\mathrm{CC}=1.15 \pm 0.02$ vs. $\mathrm{CT}=1.19 \pm 0.01$ vs. 1.18 $\pm 0.02 \mathrm{~kg} / \mathrm{d})$. Cows that experienced disease during the lactation had lower $(P<0.01)$ yields of true protein than those that did not experience disease $(1.15 \pm 0.02 \mathrm{vs}$. $1.20 \pm 0.01 \mathrm{~kg} / \mathrm{d})$. At completion of a 305-d lactation, cows of the CT genotype tended $(P=0.08)$ to produce $282 \mathrm{~kg}$ more milk than CC cows, and they produced $258 \mathrm{~kg}$ more $3.5 \% \mathrm{FCM}(P=0.04), 12 \mathrm{~kg}$ more fat $(P=$ $0.05)$, and $10.7 \mathrm{~kg}$ more true protein $(P=0.01)$ than $\mathrm{CC}$ cows, although only protein production differed between CT and TT cows (Table 3).

There was a tendency $(P=0.07)$ for the leptin genotype to influence SCS and they were $2.54 \pm 0.13,2.78$ \pm 0.12 , and $2.48 \pm 0.14$ for CC, CT, and TT cows, respectively (Table 2). The SCS did not differ between parity, but cows that experienced disease during lactation had greater $(P<0.01)$ SCS than those that did not experience any disease $(3.01 \pm 0.13$ vs. $2.19 \pm 0.10)$. The proportions of cows with subclinical mastitis, based on SCC $>200 \times 10^{3} / \mathrm{mL}$ in any of the first 10 mo postpartum were similar $(P>0.12)$ for the different genotypes, and approximately $16.8 \%$ of the cows had subclinical mastitis at any given month postpartum.

\section{Incidence of Health and Calving Disorders}

Risk of retained fetal membranes was not influenced by leptin genotype, and it affected $5.8 \%$ of the cows (Table 4$)$. Leptin genotype was associated $(P=0.02)$ 
Table 2. Lactation performance of cows with different leptin genotypes (LSM \pm SEM)

\begin{tabular}{|c|c|c|c|c|c|c|c|c|c|}
\hline \multirow[b]{2}{*}{ Item } & \multicolumn{6}{|c|}{ Leptin genotype $(\mathrm{LG})^{1}$} & & & \\
\hline & Primiparous & Multiparous & Primiparous & Multiparous & Primiparous & Multiparous & LG & Parity & LG $\times$ Parity \\
\hline $\begin{array}{l}\text { Previous lactation } \\
\text { Milk, kg/d }\end{array}$ & - & $39.6 \pm 0.4$ & - & $40.4 \pm 0.4$ & - & $39.6 \pm 0.6$ & 0.06 & - & - \\
\hline $\begin{array}{l}\text { Current lactation } \\
\text { Milk, kg/d } \\
3.5 \% \text { FCM, kg/d } \\
\text { Milk fat }\end{array}$ & $\begin{array}{l}35.4 \pm 0.7 \\
34.5 \pm 0.8\end{array}$ & $\begin{array}{l}42.8 \pm 0.6 \\
43.8 \pm 0.7\end{array}$ & $\begin{array}{l}36.0 \pm 0.7 \\
36.2 \pm 0.8\end{array}$ & $\begin{array}{l}44.1 \pm 0.5 \\
45.4 \pm 0.6\end{array}$ & $\begin{array}{l}37.1 \pm 0.9 \\
37.5 \pm 1.0\end{array}$ & $\begin{array}{l}43.0 \pm 0.8 \\
44.4 \pm 0.9\end{array}$ & $\begin{array}{l}0.23 \\
0.02\end{array}$ & $\begin{array}{l}<0.01 \\
<0.01\end{array}$ & $\begin{array}{l}0.15 \\
0.15\end{array}$ \\
\hline$\%$ & $\begin{array}{l}3.49 \pm 0.05 \\
1.21 \pm 0.03\end{array}$ & $\begin{array}{l}3.59 \pm 0.04 \\
1.53 \pm 0.02\end{array}$ & $\begin{array}{l}3.59 \pm 0.05 \\
1.27 \pm 0.03\end{array}$ & $\begin{array}{l}3.62 \pm 0.04 \\
1.59 \pm 0.02\end{array}$ & $\begin{array}{l}3.60 \pm 0.06 \\
1.31 \pm 0.03\end{array}$ & $\begin{array}{l}3.62 \pm 0.06 \\
1.55 \pm 0.03\end{array}$ & $\begin{array}{l}0.22 \\
0.02\end{array}$ & $\begin{array}{r}0.15 \\
<0.01\end{array}$ & $\begin{array}{l}0.50 \\
0.15\end{array}$ \\
\hline $\begin{array}{l}\% \\
\mathrm{~kg} / \mathrm{d} \\
\text { SCS }\end{array}$ & $\begin{array}{l}2.96 \pm 0.02^{\mathrm{b}} \\
1.02 \pm 0.02 \\
2.51 \pm 0.16\end{array}$ & $\begin{array}{l}2.99 \pm 0.02^{\mathrm{ab}} \\
1.29 \pm 0.02 \\
2.58 \pm 0.13\end{array}$ & $\begin{array}{l}3.01 \pm 0.02^{\mathrm{a}} \\
1.05 \pm 0.02 \\
2.85 \pm 0.15\end{array}$ & $\begin{array}{l}2.99 \pm 0.02^{\mathrm{ab}} \\
1.33 \pm 0.01 \\
2.72 \pm 0.12\end{array}$ & $\begin{array}{l}2.95 \pm 0.03^{\mathrm{b}} \\
1.07 \pm 0.02 \\
2.35 \pm 0.19\end{array}$ & $\begin{array}{l}3.01 \pm 0.02^{\mathrm{a}} \\
1.30 \pm 0.02 \\
2.61 \pm 0.17\end{array}$ & $\begin{array}{l}0.28 \\
0.04 \\
0.07\end{array}$ & $\begin{array}{r}0.06 \\
<0.01 \\
\\
0.49\end{array}$ & $\begin{array}{l}0.04 \\
0.40\end{array}$ \\
\hline
\end{tabular}

a,b Values with different superscripts in the same row differ $(P<0.05)$.

${ }^{1}$ Leptin genotype: a $\mathrm{C} / \mathrm{T}$ substitution resulting in an amino acid change from arginine to cysteine.

Table 3. Lactation yields at 305-d of cows with different leptin genotype (LSM \pm SEM)

\begin{tabular}{lrrrr}
\hline & \multicolumn{3}{c}{ Leptin genotype $^{1}$} & \\
\cline { 2 - 4 } 305-d production, kg & \multicolumn{1}{c}{ CC } & CT & TT & -value \\
\hline Milk & $12,248 \pm 106$ & $12,530 \pm 90$ & $12,304 \pm 150$ & 0.10 \\
3.5\% FCM & $12,109 \pm 76^{\mathrm{b}}$ & $12,367 \pm 65^{\mathrm{a}}$ & $12,287 \pm 109^{\mathrm{ab}}$ & 0.04 \\
Milk fat & $423.7 \pm 3.0^{\mathrm{b}}$ & $435.7 \pm 2.6^{\mathrm{a}}$ & $432.1 \pm 4.3^{\mathrm{ab}}$ & 0.05 \\
Milk true protein & $357.8 \pm 2.1^{\mathrm{b}}$ & $368.5 \pm 1.8^{\mathrm{a}}$ & $361.1 \pm 2.9^{\mathrm{b}}$ & 0.01 \\
\hline
\end{tabular}

${ }^{\mathrm{a}, \mathrm{b}}$ Values with different superscripts in the same row differ $(P<0.05)$.

${ }^{1}$ Leptin genotype: a $\mathrm{C} / \mathrm{T}$ substitution resulting in an amino acid change from arginine to cysteine.

Table 4. Incidence of health disorders of cows with different leptin genotypes

\begin{tabular}{|c|c|c|c|c|}
\hline \multirow[b]{2}{*}{ Disorder } & \multicolumn{3}{|c|}{ Leptin genotype $^{1}$} & \multirow[b]{2}{*}{$P$-value } \\
\hline & $\mathrm{CC}$ & $\mathrm{CT}$ & $\mathrm{TT}$ & \\
\hline \multicolumn{5}{|c|}{ Retained placenta } \\
\hline$\%(\mathrm{n} / \mathrm{n})$ & $7.1(20 / 282)$ & $4.6(18 / 392)$ & $6.4(9 / 140)$ & \\
\hline $\mathrm{AOR}(95 \% \mathrm{CI})^{2}$ & $1.07(0.47,2.44)$ & $0.67(0.29,1.53)$ & Referent & 0.34 \\
\hline \multicolumn{5}{|c|}{ Displaced abomasum } \\
\hline$\%(\mathrm{n} / \mathrm{n})$ & $1.4(4 / 282)^{\mathrm{ab}}$ & $0.5(2 / 392)^{b}$ & $4.3(6 / 140)^{\mathrm{a}}$ & \\
\hline $\mathrm{AOR}(95 \% \mathrm{CI})$ & $0.32(0.08,1.14)$ & $0.12(0.02,0.57)$ & Referent & 0.02 \\
\hline \multicolumn{5}{|l|}{ Mastitis } \\
\hline$\%(\mathrm{n} / \mathrm{n})$ & $13.5(38 / 282)$ & $12.8(50 / 392)$ & $18.6(26 / 140)$ & \\
\hline $\mathrm{AOR}(95 \% \mathrm{CI})$ & $0.65(0.38,1.14)$ & $0.61(0.36,1.03)$ & Referent & 0.16 \\
\hline \multicolumn{5}{|l|}{ Lameness } \\
\hline$\%(\mathrm{n} / \mathrm{n})$ & $3.9(11 / 282)$ & $2.6(10 / 392)$ & $3.6(5 / 140)$ & \\
\hline $\mathrm{AOR}(95 \% \mathrm{CI})$ & $1.09(0.37,3.19)$ & $0.70(0.24,2.09)$ & Referent & 0.59 \\
\hline \multicolumn{5}{|l|}{ Any disease } \\
\hline$\%(\mathrm{n} / \mathrm{n})$ & $24.1(68 / 282)^{\mathrm{ab}}$ & $19.6(77 / 392)^{\mathrm{b}}$ & $29.3(41 / 140)^{\mathrm{a}}$ & \\
\hline AOR $(95 \%$ CI $)$ & $0.74(0.46,1.17)$ & $0.56(0.35,0.87)$ & Referent & 0.004 \\
\hline \multicolumn{5}{|l|}{ Multiple diseases } \\
\hline$\%(\mathrm{n} / \mathrm{n})$ & $3.2(9 / 282)$ & $1.5(6 / 392)$ & $5.0(7 / 140)$ & \\
\hline $\mathrm{AOR}(95 \% \mathrm{CI})$ & $0.63(0.23,1.72)$ & $0.30(0.10,0.89)$ & Referent & 0.10 \\
\hline
\end{tabular}

${ }^{\mathrm{a}, \mathrm{b}}$ Values with different superscripts in the same row differ $(P<0.05)$.

${ }^{1}$ Leptin genotype: a $\mathrm{C} / \mathrm{T}$ substitution resulting in an amino acid change from arginine to cysteine.

${ }^{2} \mathrm{AOR}=$ adjusted odds ratio; $\mathrm{CI}=$ confidence interval. 
Table 5. Calving difficulty, dystocia, stillbirth, and calf gender according to leptin genotype of the dam

\begin{tabular}{|c|c|c|c|c|}
\hline \multirow[b]{2}{*}{ Item } & \multicolumn{3}{|c|}{ Leptin genotype $^{1}$} & \multirow[b]{2}{*}{$P$-value } \\
\hline & $\mathrm{CC}$ & $\mathrm{CT}$ & $\mathrm{TT}$ & \\
\hline \multicolumn{5}{|l|}{ Calving score } \\
\hline $\mathrm{LSM} \pm \mathrm{SEM}$ & $1.52 \pm 0.11$ & $1.51 \pm 0.12$ & $1.34 \pm 0.13$ & 0.20 \\
\hline Median (mean rank) & $1.0(414)$ & $1.0(410)$ & $1.0(389)$ & 0.24 \\
\hline \multicolumn{5}{|l|}{ Dystocia $^{2}$} \\
\hline$\%(\mathrm{n} / \mathrm{n})$ & $13.8(39 / 282)$ & $12.8(50 / 392)$ & $8.6(12 / 140)$ & \\
\hline $\mathrm{AOR}(95 \% \mathrm{CI})^{3}$ & $1.75(0.86,3.54)$ & $1.58(0.80,3.14)$ & Referent & 0.30 \\
\hline \multicolumn{5}{|l|}{ Stillbirth } \\
\hline$\%(\mathrm{n} / \mathrm{n})$ & $14.5(41 / 282)$ & $12.8(50 / 392)$ & $9.3(13 / 140)$ & \\
\hline AOR (95\% CI) & $1.67(0.85,3.28)$ & $1.41(0.73,2.72)$ & Referent & 0.33 \\
\hline \multicolumn{5}{|l|}{ Female calves } \\
\hline$\%$ all calves $(\mathrm{n} / \mathrm{n})$ & $45.8(129 / 282)$ & $40.8(160 / 392)$ & $48.6(68 / 140)$ & \\
\hline AOR (95\% CI) & $1.12(0.75,1.67)$ & $1.28(0.87,1.87)$ & Referent & 0.41 \\
\hline \multicolumn{5}{|c|}{ Twins (male and females) } \\
\hline$\%$ all calves $(\mathrm{n} / \mathrm{n})$ & $6.0(17 / 282)$ & $3.3(13 / 392)$ & $5.0(7 / 140)$ & \\
\hline AOR $(95 \%$ CI $)$ & $1.12(0.47,2.92)$ & $0.60(0.23,1.56)$ & Referent & 0.21 \\
\hline
\end{tabular}

with the incidence of displacement of the abomasum, and cows homozygous for the $\mathrm{T}$ allele were more likely $(P<0.01)$ to experience displacement of the abomasum compared with cows bearing the CT genotype. A total of $114(14.0 \%)$ cows experienced at least one case of clinical mastitis, and it was not $(P=0.16)$ associated with leptin genotype. Similar to mastitis, leptin genotype did not alter the risk of lameness.

The risk of cows to be affected by at least one of the diseases described above was associated $(P=0.004)$ with leptin genotype, and cows with the CT genotype were less likely to experience disease compared with $\mathrm{CC}$ and TT cows, but there was no $(P=0.17)$ difference between $\mathrm{CC}$ and TT cows (Table 4). Interestingly, there was a tendency $(P=0.10)$ for the leptin genotype to be associated with the risk of cows developing multiple diseases during their lactation (Table 4), and CT cows had the least risk.

The mean and median calving scores of cows of different genotypes were similar (Table 5). Similarly, genotype was not associated with the proportion of cows experiencing dystocia, stillbirths, delivering female calves, or having twin births.

\section{DISCUSSION}

Considerable interest exists in determining the relationship between SNP for different genes and productive and health traits of economic importance for the cattle industry. Recently, a $\mathrm{C}$ to $\mathrm{T}$ transition in the $\mathrm{R} 4 \mathrm{C}$ locus of exon 2 of the leptin gene, which encodes an amino acid change from arginine to cysteine, was identified (Konfortov et al., 1999). Such a change is considered a nonconserved substitution that could alter the functionality of the leptin hormone and was linked with changes in important economic traits of beef and dairy cattle (Konfortov et al., 1999; Buchanan et al., 2002, 2003). In the present study, the distribution of dairy cows with CC, CT, and TT genotypes was 34.6, 48.2, and $17.2 \%$, respectively, resulting in $82.8 \%$ of cows bearing the $\mathrm{C}$ allele and $65.4 \%$ bearing the $\mathrm{T}$ allele. This prevalence of cows bearing $\mathrm{C}$ and $\mathrm{T}$ alleles was similar to that reported for Holstein cattle (Buchanan et al., 2003), which probably reflects the similar gene pool used by different dairy producers that rely upon proven sires from bull studs for AI.

Cows bearing the CT genotype tended to have lower BCS during the first 62 DIM compared with those bearing TT and CC genotypes. This is an intriguing finding considering that cows with the CT genotype only had greater yield of FCM compared with CC cows, but not TT cows. It was demonstrated that polymorphisms in the coding region of the leptin gene were associated with DMI (Liefers et al., 2002; Lagonigro et al., 2003) and carcass merit (Nkrumah et al., 2004), and that animals homozygous for the $\mathrm{T}$ allele in exon 2 of the leptin gene had greater body fat and grade fat compared with those homozygous for the $\mathrm{C}$ allele (Buchanan et al., 2002). Cows with the CT genotype had lower BCS during the first 62 DIM compared with TT cows, despite having similar milk yield, which could be an indication that the latter may have had greater feed intake during early stages of lactation or that they may be more competent in storing energy as fat depots and have less energy expenditure. 
Cows with the CT genotype tended to have greater milk production compared with cows homozygous for the $\mathrm{C}$ and $\mathrm{T}$ alleles during the lactation before enrollment in this study. Cows of the same leptin genotype produced more 305-d 3.5\% FCM, milk fat, and true protein than cows of the CC genotype. Buchanan et al. (2003) observed that cows homozygous for the $\mathrm{C}$ allele had lower milk yield than those bearing CT and TT genotypes. On the other hand, CC cows tended to have greater fat concentration in milk from 101 to 200 DIM compared with CT and TT cows, resulting in similar FCM yields among cows of different leptin genotypes (Buchanan et al., 2003), which contrasts our results. Silva et al. (2002) demonstrated that bovine mammary epithelial cell lines cultured in the presence of leptin had less incorporation of $\left[{ }^{3} \mathrm{H}\right]$-thymidine, which indicated less DNA synthesis, suggesting a negative feedback role of leptin on mammary gland development. Contrary to these findings, Thorn et al. (2006) observed that bovine mammary epithelial cells had negligible leptin receptor expression and did not respond to leptin in vitro; thereby, indicating that leptin could not influence lactation by acting directly on mammary epithelial cells. Therefore, changes in lactation performance observed for cows of different leptin genotype were likely the result of differences in partition of nutrients with CT cows prioritizing yields of milk and milk components as opposed to CC cows that stored more body reserves, which later in lactation might reflect in differences in serum leptin concentrations (Liefers et al., 2003).

As expected, cows that experienced at least one disease event during their lactation had reduced productivity and yielded 2.2 and $2.7 \mathrm{~kg} / \mathrm{d}$ less milk and 3.5\% FCM, respectively, compared with healthy cows. This was expected as all the diseases evaluated reduce lactation performance of dairy cows (Rajala and Gröhn, 1998; Hernandez et al., 2005).

Interestingly, CT cows tended to have greater SCS than TT and CC cows, even though the risk for clinical mastitis did not differ among genotypes. Increased SCC in milk in the absence of clinical signs of mastitis could indicate an increased occurrence of subclinical mastitis in CT cows; however, the proportions of cows that experienced subclinical mastitis based on SCC $>200 \times 10^{3} /$ $\mathrm{mL}$ were similar among genotypes. Buchanan et al. (2003) observed that cows homozygous for the T allele had significantly greater SCS compared with CC and CT cows, but no data regarding incidence of clinical mastitis was presented. These data suggest that risk for mastitis was not influenced by leptin genotype.

In the present study, there was no association between leptin genotype and incidence of lameness. It is important to note that the incidence of lameness observed in the present study was considerably less than that observed previously (Hernandez et al., 2005; Espejo et al., 2006). Espejo et al. (2006) observed that when lameness was diagnosed by study personnel the incidence was approximately 3.1 times greater compared with the observed incidence of lameness when farm personnel were responsible for its diagnosis.

Cows of TT genotype more likely experienced displacement of the abomasum compared with CT cows. Displacement of abomasum usually occurs in cows with depressed appetite prepartum and early postpartum, and a major risk factor is excessive degree of fatness at calving, which results in delayed postpartum increase in DMI (Van Winden and Kuiper, 2003). Furthermore, cows with high BCS during the last $30 \mathrm{~d}$ before calving had increased concentrations of NEFA and BHBA during the transition period (Bernabucci et al., 2005), indicating that they underwent more severe negative nutrient balance. In the current study, cows homozygous for the $\mathrm{T}$ allele tended to have the highest BCS throughout the study, but differences were too small to justify major increments in the risk for displacement of abomasum, and mean BCS at $3 \mathrm{~d}$ postpartum does not suggest that cows were overconditioned immediately before calving. Another risk factor for postparturient diseases was calving-related problems, which did not differ among genotypes. Because TT cows experienced not only increased risk for displacement of abomasum, but also overall morbidity and risk for multiple diseases, it is possible that cows bearing the homozygous $\mathrm{T}$ allele were more susceptible to postparturient diseases.

Interestingly, heterozygous cows not only produced more 3.5\% FCM and milk components, they also experienced the lowest risk for displacement of abomasum, morbidity, and multiple diseases. Inbreeding has been demonstrated to be detrimental to health and production, and heterozygosis reduces the consequences of inbreeding depression, maintaining genetic interactions that result in improved productive and health performance (VanRaden and Sanders, 2003).

\section{CONCLUSIONS}

It is known that other polymorphisms in the leptin gene that could affect productivity and health traits of dairy animals exist, and that productive responses to polymorphisms of the R4C locus of exon 2 of the leptin gene have not been consistent in dairy cows. Yet, in the current study, cows bearing the CT genotype had lower BCS than CC or TT cows during the first 62 DIM, which could be explained by their increased monthly yields of $3.5 \%$ FCM, milk fat, and true protein, resulting in greater 305-d yields of milk and milk components. Cows homozygous for the $\mathrm{T}$ allele had greater BCS during 
the first 62 DIM compared with CT cows, despite having similar yields of milk and 3.5\% FCM, which could indicate that they had greater feed intake or were more efficient in energy expenditure and storage. Heterozygous cows were less likely to experience disease during their lactation compared with cows homozygous for the $\mathrm{C}$ and $\mathrm{T}$ alleles. Heterozygosis in the R4C locus in exon 2 of the leptin gene appears to confer on dairy cows characteristics of hybrid vigor. Therefore, mating decisions to increase the frequency of cows heterozygous in the $\mathrm{R} 4 \mathrm{C}$ locus may improve productive and health performance.

\section{ACKNOWLEDGMENTS}

The authors want to thank Brent Woodward from Merial (Duluth, GA) for providing the Igenity L genotype testing for this study.

\section{REFERENCES}

Association of Official Analytical Chemists. 2000. Official Methods of Analysis. 17th ed. AOAC, Gaithersburg, MD.

Bernabucci, U., B. Ronchi, N. Lacetera, and A. Nardone. 2005. Influence of body condition score on relationships between metabolic status and oxidative stress in periparturient dairy cows. J. Dairy Sci. 88:2017-2026.

Block, S. S., J. M. Smith, R. A. Ehrhardt, M. C. Diaz, R. P. Rhoads, M. E. Van Amburgh, and Y. R. Boisclair. 2003. Nutritional and developmental regulation of plasma leptin in dairy cattle. J. Dairy Sci. 86:3206-3214.

Buchanan, F. C., C. J. Fitzsimmons, A. G. Van Kessels, T. D. Thue, C. Winkelman-Sim, and S. M. Schumtz. 2002. Association of a missense mutation in the bovine leptin gene with carcass fat content and leptin mRNA levels. Genet. Sel. Evol. 34:105-116.

Buchanan, F. C., A. G. Van Kessel, C. Waldner, D. A. Christensen, B. Laarveld, and S. M. Schumtz. 2003. An association between a leptin single nucleotide polymorphism and milk and protein yield. J. Dairy Sci. 86:3164-3166.

Cunningham, M. J., D. K. Clifton, and R. A. Steuner. 1999. Leptin's actions on the reproductive axis: Perspective and mechanisms. Biol. Reprod. 60:216-222.

Espejo, L. A., M. I. Endres, and J. A. Salfer. 2006. Prevalence of lameness in high-producing Holstein cows housed in freestall barns in Minnesota. J. Dairy Sci. 89:3052-3058.

Ferguson, J. D., D. T. Galligan, and N. Thomsen. 1994. Principal descriptors of body condition score in Holstein cows. J. Dairy Sci. 77:2695-2703.

Hernandez, J. A., E. J. Garbarino, J. K. Shearer, C. A. Risco, and W. W. Thatcher. 2005. Comparison of milk yield in dairy cows with different degrees of lameness. J. Am. Vet. Med. Assoc. 227:1292-1296.

Houseknecht, K. L., C. A. Baile, R. L. Matteri, and M. E. Spurlock. 1998. The biology of leptin: A review. J. Anim. Sci. 76:1405-1420.

Kadokawa, H., D. Blache, Y. Yamada, and G. B. Martin. 2000. Relationships between changes in plasma concentrations of leptin before and after parturition and the timing of first post-partum ovulation in high-producing Holstein dairy cows. Reprod. Fertil. Dev. 12:405-411.

Kaminski, S., P. Brym, A. Rusc, and E. Wojcik. 2006. Associations between milk performance traits in Holstein cows and 16 candidate SNPs identified by arrayed primer extension (apex) microarray. Anim. Biotechnol. 17:1-11.

Konfortov, B. A., V. E. Licence, and J. R. Miller. 1999. Re-sequencing of DNA from a diverse panel of cattle reveals a high level of polymorphism in both intron and exon. Mamm. Genome 10:1142-1145.

Lagonigro, R., P. Wiener, F. Pilla, J. A. Woolliams, and J. L. Williams. 2003. A new mutation in the coding region of the bovine leptin gene associated with feed intake. Anim. Genet. 34:371-374.

Liefers, S. C., M. F. W. te Pas, R. F. Veerkamp, Y. Chilliard, C. Delavaud, R. Gerritsen, and T. van der Lende. 2003. Association of leptin gene polymorphisms with serum leptin concentration in dairy cows. Mamm. Genet. 14:657-663.

Liefers, S. C., M. F. W. te Pas, R. F. Veerkamp, and T. van der Lende. 2002. Association between leptin gene polymorphisms and production, live weight, energy balance, feed intake and fertility in Holstein heifers. J. Dairy Sci. 85:1633-1638.

Liefers, S. C., R. F. Veerkamp, M. F. W. Te Pas, Y. Chilliard, and T. Van der Lende. 2005. Genetics and physiology of leptin in periparturient dairy cows. Domest. Anim. Endocrinol. 29:227238.

Lord, G. M., G. Matarese, J. K. Howard, R. J. Baker, S. R. Bloom, and R. I. Lechler. 1998. Leptin modulates the T-cell immune response and reverses starvation-induced immunosuppression. Nature 394:897-900.

Nkrumah, J. D., C. Li, J. A. Basarab, S. Guercio, Y. Meng, B. Murdoch, C. Hansen, and S. S. Moore. 2004. Association of a single nucleotide polymorphism in the bovine leptin gene with feed intake, growth, feed efficiency, feeding behavior and carcass merit. Can. J. Anim. Sci. 84:211-219.

Nkrumah, J. D., C. Li, J. Yu, C. Hansen, D. H. Keisler, and S. S. Moore. 2005. Polymorphisms in the bovine leptin promoter associated with serum leptin concentration, growth, feed intake, feeding behavior, and measures of carcass merit. J. Anim. Sci. 83:20-28.

NRC. 2001. Nutrient Requirements of Dairy Cattle. 7th ed. Natl. Acad. Press, Washington, DC.

Rajala, P. J., and Y. T. Gröhn. 1998. Effects of dystocia, retained placenta, and metritis on milk yield in diary cows. J. Dairy Sci. 81:3172-3181.

Silva, L. F., M. J. VandeHaar, M. S. Weber Nielsen, and G. W. Smith. 2002. Evidence for a local effect of leptin in bovine mammary gland. J. Dairy Sci. 85:3277-3286.

Thorn, S. R., S. Purup, W. S. Cohick, M. Vestergaard, K. Sejrsen, and Y. R. Boisclair. 2006. Leptin does not act directly on mammary epithelial cells in prepubertal dairy heifers. J. Dairy Sci. 89:1467-1477.

VanRaden, P. M., and A. H. Sanders. 2003. Economic merit of crossbred and purebred US dairy cattle. J. Dairy Sci. 86:1036-1044.

Van Soest, P. J., J. B. Robertson, and B. A. Lewis. 1991. Methods for dietary fiber, neutral detergent fiber, and nonstarch polysaccharides in relation to animal nutrition. J. Dairy Sci. 74:35833597.

Van Winden, S. C., and R. Kuiper. 2003. Left displacement of the abomasum in dairy cattle: recent developments in epidemiological and etiological aspects. Vet. Res. 34:47-56.

Zhang, Y., R. Proenca, M. Maffei, M. Barone, L. Leopold, and J. M. Friedman. 1994. Positional cloning of the mouse obese gene and its human homologue. Nature 372:425-432. 